Kozlovska I. (2015). The impact of long-lived non-financial assets depreciation/ amortization method on financial statements. Copernican Journal of Finance \& Accounting, 4(2), 91-108. http://dx.doi.org/10.12775/CJFA.2015.018

\author{
Ieva Kozlovska*
}

Riga Business School

\title{
THE IMPACT OF LONG-LIVED NON-FINANCIAL ASSETS DEPRECIATION/AMORTIZATION METHOD ON FINANCIAL STATEMENTS
}

Keywords: non-financial long-lived assets, depreciation method, amortization method, accounting policy, financial statements.

\section{J E L Classification: M410.}

Abstract: Non-financial long-lived assets are ones ensuring company's basic business operations, with expected useful time more than one accounting period, and generating profit. Assets often requiring significant investments constitute also considerable part of companies' total assets in its statements of financial position. In average this proportion in balance sheets of Latvian companies listed in Baltic stock exchange is $48 \%$. In most of these companies this percentage is higher and even up to $97 \%$.

Due to nowadays global economic situation the management of non-financial long-lived assets also plays significant role in both - shareholders' (actual/ potential) and management's - decision-making processes concerning investing, financing, controlling, other activities. In order to ensure financial statements reflects real situation of the particular company, company's management is responsible to ensure that accounting process of depreciation/ amortization these assets is:

- Correct, transparent and in line with specifics of company's business;

- In accordance with respective accounting and reporting regulations.

Date of submission: August 25, 2015; date of acceptance: October 27, 2015.

* Contact information: ieva.kozlovska@ba.lv, Kr.Valdemara Street 161, Riga, LV-1013, Latvia, phone: 00371-2-9995999. 
This article reveals theoretical and practical view exploring how information relating depreciation/ amortization of long-lived non-financial assets influences results in financial statements of Latvian companies listed in Baltic stock exchange.

\section{IIIITRODUCTION}

In various businesses long-lived non-financial assets are one of the most significant items in the company's balance sheet ensuring basic business operations, and also one basically generating profit.

Opinions expressed by foreign researchers are that depreciation/ amortization expense is informative about company's depreciation policy and depreciation/ amortization methods have significant influence over investment decisions taken by company's management and shareholders. Usually selection of particular depreciation method is based on the company's financial policy and available amount of financial resources to be invested. Depreciation policies allow to modulate company's self-financing flows among years. The linear depreciation method is the one used most often by companies (Ilincuta 2013). Therefore, today long-lived non-financial assets management plays really significant role as in company's accounting process as in company's management and stakeholders' or even potential investors decision-making processes concerning investing, financing, controlling and other activities.

Acquiring a long-lived asset its cost should be accounted as asset's initial value. Since this asset is used to generate profit also related depreciation/ amortization expenses to generate revenues should be accounted. These expenses reflect the cost of the particular non-current asset used up to generating revenue. The depreciation/ amortization expenses should be recognized in the company's income statement which very often can be also a very large item. There are various methods of depreciation/ amortization calculation. In situation when different depreciation/ amortization methods for the same long-lived non-financial assets are applied also the result per financial period can differ quite substantially. Therefore, the policy defining how company's long-lived assets should be depreciated/ amortized has significant impact also on the calculated income. These expenses similar as impairment losses are accounted as noncash expenses. The company's management before selecting new or evaluating existing depreciation/ amortization method of long-lived non-financial assets should consider various important issues. It is responsible to ensure that accounting process of these long-lived assets is correct, transparent and in accordance with respective accounting and reporting regulations. 
The key purpose of the article was to:

- explore aspects to consider analysing information about long-lived non-financial assets reflected in financial statements;

- develop recommendations what kind of issues the company should consider selecting the most appropriate amortization/ depreciation method of non-financial long-lived assets.

Author examines possible methods and ways how to gain better understanding of financial position of business regarding company's ability to use its long-lived non-financial assets. Mainly it reveals how to evaluate the information about depreciation/ amortization of long-lived non-financial assets in the company's financial statements.

The Author's conclusions are based on the study of Western publications and analysis of practices in Latvian companies listed in Baltic stock exchange.

The main principles of accounting regulation of depreciation/ amortization of long-lived non-financial assets are formulated in IAS16 and IAS38 for Latvian listed companies in Baltic stock exchange and Latvian accounting standard nb.7 for other companies except Latvian listed companies in Baltic stock exchange.

The results of the study allowed the Author to identify specific problems and patterns in accounting practice as well as formulate directions for further research aimed at developing an accounting policy for accounting measurement of long-lived non-financial assets for various types of companies.

This article may be of interest to management and shareholders (existing/ potential) of the particular company, financial statement users, regulators, standards setters, and financial analysts.

\section{RESEARCH METHODOLOGY AND RESEARCH PROCESS}

Research problem - assets side of the balance sheet compromises both - "current" and "fixed" assets - also often called "long-term" or "long-lived" assets.

Long-lived assets are:

- material and value investments with usage period more than one financial year;

- ones that reflect company's capability and capacity that allows company's operating-cycle to take place;

- ones that create economic benefit - generating profit - for the particular company for more than one accounting period; 
- ones that have significant investments before an activity can take place;

- are not intended to be sold to company's customers. In this case this asset should be accounted as inventory;

- ones that ensures investment's recovery as a result of usage, etc.;

- very often ones that represent significant portion of company's total assets;

- ones that should be depreciated/ amortized over its useful life or its recognition of expenses in the income statement.

Since long-lived non-financial assets are used to generate profit for the company also related depreciation/ amortization expenses to generate these revenues should be accounted. Summarizing the theory there are various methods for calculation of long-lived non-financial assets depreciation/ amortization straight-line method, increasing/ decreasing charge method, interest method, production method, revaluation method, double declining balance method, diminishing rate and cost method, straight line method with rate changes, free curve depreciation method, sum of the year digit method of depreciation, reverse of sum of the year digit method of depreciation, annuity method, production method, straight line method by usage factor, working hour method, efficiency hours method, depletion unit method or production unit method, the use or mileage method, decline unit use charge, revaluation method, insurance policy method, job method, combination of time and usage factor, depreciation based on average, global method, statutory method, examination method, percentage of revenue method, statistical method, depletion method, repairs/ replacement reserve method, retirement or replacement method, other methods.

The Author found out that based on International Financial Reporting Standards - IFRS - and also Latvian accounting standard nb.7 the company is allowed to apply only following three out of all depreciation/ amortization methods mentioned above - straight-line method, units production method, and diminishing balance or reducing balance method.

Research related to depreciation/ amortization in Scientific Literature - the Author of this article reviewed the research publications by foreign Authors in order to study the degree of this topic development in the international scientific literature. On the basis of the results of the theoretical study the Author concluded that the interests of foreign researchers are mainly focused on the following research fields - theories and various issues relating depreciation/ amortization of long-lived non-financial assets, policy of long-lived non-financial assets depreciation/ amortization, methods of long-lived non-financial as- 
sets, legislation, practical issues - depreciation/ amortization and performance management. Table 1 summarizes the results of the study of the viewpoints of some foreign researchers in the research fields listed above.

Table 1. Depreciation/ amortization of long-lived non-financial assets: researchers' views on the problem

\begin{tabular}{|c|c|}
\hline Researcher(s) & $\begin{array}{l}\text { Main research idea/conclusion by the opinion } \\
\text { of the Author of the paper }\end{array}$ \\
\hline $\begin{array}{l}\text { Brundage P.F. (1935), Wright F.K. (1964), Brigham E.F. } \\
\text { (1966), Brief R.P. (1967), Archibald T.R. (1967), } \\
\text { Voss W.M. (1968), Feinschreiber R. (1969), Livingstone } \\
\text { J.L. (1969), Feinschreiber R. (1969), Baxter W.T. (1970), } \\
\text { Wolk H.I. (1970), Beaver W.H., Dukes R.E. (1974), Ac- } \\
\text { countancy (1980), Dilley S.C., Young J.C. (1994), Cog- } \\
\text { gins M. (1995), Hwang J.C. (2002/2003), Storchmann } \\
\text { K. (2004), Cernuşca L. (2009), Mykolaitiene V., Vecer- } \\
\text { skiene G., Jankauskiene K., Valanciene L. (2010), Noland } \\
\text { T.R. (2010), Huagan N., Diewert E. (2011), Stadig M. } \\
\text { (2011), }\end{array}$ & $\begin{array}{l}\text { Various evaluation methods; key factors influenc- } \\
\text { ing depreciation; relationship between depreciation } \\
\text { methods; economic and physical depreciations; key } \\
\text { rules relating issues of amortization of intangible as- } \\
\text { sets; depreciation and company performance. }\end{array}$ \\
\hline $\begin{array}{l}\text { Davidson S. (1950), Eisner R. (1955), Hellmuth JR., Wil- } \\
\text { liam F. (1955), Brigham E.F. (1968), Brief R.P. (1968), } \\
\text { Levy H., Arditti F.D. (1973), Butler G., Crawford L. (2001), } \\
\text { Jackson S.B. (2008), Jackson S.B. (2008), Aparicio J., } \\
\text { Sánchez-Soriano, J (2008), Mohman M.B. (2009), Rajan } \\
\text { M., Reichelstein S. (2009), Sok-yon K., Yuping Z. (2010), } \\
\text { Radu D., Marius D (2011), Boudreaux D.O., Rao S., Un- } \\
\text { derwood J., Rumore N. (2011), Watts M.M. (2011), } \\
\text { Koowattanatianchai N., Wang J., Charles M.B. (2012), } \\
\text { Birky K., Grimstad E. (2013), llincuta, L. (2013), Valipour } \\
\text { H., Moradi J., Farzanfar F. (2013), Birky K., Grimstad E. } \\
\text { (2013), }\end{array}$ & $\begin{array}{l}\text { Discussed that depreciation/ amortization policy and } \\
\text { its calculation methods have significant influence } \\
\text { over the level of reported profit per particular period } \\
\text { in the financial statements of the particular company, } \\
\text { share price, future benefits and abnormal return of } \\
\text { the shares and reserves, value of the company, com- } \\
\text { pany's price control regulations, strategy, structure, } \\
\text { ownership, future benefits, benefits of tax savings, } \\
\text { existence of cross-subsidiaries, income, expense and } \\
\text { capital gain accounts, various investment decisions } \\
\text { taken by companies' management and shareholders } \\
\text { in many countries all over the world. }\end{array}$ \\
\hline $\begin{array}{l}\text { Bain J.S. (1937), Lev B., Theil H. (1978), Luger M.I. (1986), } \\
\text { Brannon G.M.(1972), Jones J.R. (1980), Lepãdatu G. } \\
\text { (2009), Trifan A., Anton C.E. (2010), O’Bannon I.M. } \\
\text { (2011), Jermakowicz E.K Epstein B.J. (2011), Beuer A., } \\
\text { Frumuşanu M.L., Pereş C.E., Breuer B.G. (2011), } \\
\text { Wong A., Pitt A.J.(2012), }\end{array}$ & $\begin{array}{l}\text { Information reflecting depreciation/ amortization } \\
\text { of long-lived non-financial assets - disclosure and } \\
\text { various issues relating, how correctly disclose, report } \\
\text { the information about depreciation/ amortization } \\
\text { of long-lived assets; company's depreciation prising } \\
\text { and depreciation policy; regulations toward depre- } \\
\text { ciation/ amortization - assets depreciation range sys- } \\
\text { tem; 10-5-3 proposal; IFRS. }\end{array}$ \\
\hline $\begin{array}{l}\text { Ijiri Y., Kaplan R.S. (1970), Barnea A. (1972), Most } \\
\text { K. (1984), Cameron-Smith I., Mattiiussi F. (1989), } \\
\text { Hwang J.C. (1997), Ben-Shahar D., Sulganik E. (2009), Tri- } \\
\text { fan A., Anton C.E. (2010), Huagan N., Diewert E. (2011), } \\
\text { Budeanu M. (2012), Chou Y., Yang C., Pao C. (2012) }\end{array}$ & $\begin{array}{l}\text { Specific issues relating intangible assets - e.g. Re- } \\
\text { search \& Development, patents, etc., employees' } \\
\text { knowledge depreciation, asset's value, physical and } \\
\text { economic depreciation, useful life of assets, produc- } \\
\text { tive assets. }\end{array}$ \\
\hline
\end{tabular}

S o u r c e : The Author's own study.

The results of study of foreign researchers' opinions reveal that depreciation/ amortization of long-lived non-financial assets can influence results in financial statements of companies operating in various industries. Also, it gives 
possibility for the company's management to manipulate with the depreciation/ amortization expenses in order to reflect higher or lower net income per particular period. It is possible to do by changing depreciation/ amortization method, increasing or decreasing useful life of these assets, etc. Therefore, it is important to report relating information correctly and in accordance with respective accounting and reporting regulations. The Author can agree with the conclusion drawn by Jackson et al. in 2008 that the choice of the depreciation method of long-lived non-financial assets does have significant effect on capital investment decisions made by the company's non-executive and other managers or even shareholders. Also, Author agrees with conclusion drawn by Ilincuta et al. in 2008 that depreciation policy of long-lived non-financial assets and its calculation methods do have significant influence over various investment decisions taken by companies' management and shareholders. And that this depreciation method has been selected based on the company's financial policy and available amount of financial resources to be invested by (Ilincuta 2008).

Based on theoretical research Author concludes the following:

- the Author thinks that there is no such a method - the best method that could be applied in all companies, because:

- there is no such a one basic or the most suitable depreciation method to be applied in all companies; the method effective for one company could be ineffective for the other one;

- there are plenty of factors influencing the effectiveness of method selected by the particular company - amount of long-lived non-financial asset depreciation/ amortization expense to other expenses and income, proportion of the total amount of assets to be depreciated to total assets reflected in company's balance sheet;

- units in which the useful life of asset to be depreciated has been expressed;

- the principal by use of which the useful life of assets should be divided into accounting periods;

- length of time period the asset will be used in company's business;

- scrap value of assets.

The Author thinks that it is possible that based on application of definite depreciation/ amortization methods company's management and shareholders can take completely different decisions for asset replacement or even various capital investment decisions. By example, the straight-line method is not reflecting real usage of the definite long-term asset as it could be with units' 
production method. Especially crucial it is due to nowadays global economic situation.

In the Author's opinion before company's management selects the most appropriate depreciation/ amortization method it is necessary to take into account following criteria - industry company operates, type of long-lived nonfinancial assets, economic situation of the company, situation/ legislation, etc. in the country it operates in, global economic situation, company's investment strategies, possibilities, useful life of the asset, asset's depreciable/ amortizable amount.

However company's management and shareholders or even financial analysts should regularly evaluate the potential risk of obsolescence of long-lived non-financial assets belonging to the particular company. Effective way how to do it is by use of financial statements - information about value of these assets and its accumulated depreciation, by example, average age or average useful life. Also, these ratios helps to identify situations the company's management trying manipulating with the net income per particular period by increasing/ decreasing depreciation/ amortization expenses by changing depreciation method, increasing/ decreasing period of an asset's useful life, and decide to capitalize or not elements of the acquisition cost, by example, financial expenses, upgrade of the particular asset.

Research methodology - review of theory conducted in the previous section allowed Author to form general idea of interest in the topic "depreciation/ amortization of long-lived non-financial assets" as well as the extent of its development in the scientific literature formulating two basic research questions (RQ):

1. What are key aspects to be considered analyzing information related long-lived non-financial assets reflected in financial statements?

2. What kind of issues the company should consider selecting the most appropriate amortization/ depreciation method of non-financial long-lived assets?

To answer RQ1 and RQ2 the Author decided to analyse existing approaches and problems in Latvian companies listed in Baltic stock exchange NASDAQ. Key attention was focused on practical issues relating depreciation/ amortization methods for long-lived non-financial assets. Therefore, before Author developed the questionnaire financial statements of these companies were analysed. Questionnaire developed consisted of following five questions:

1. What depreciation/ amortization methods are applied?

2. What were key reasons to select these methods? 
3. What were key determinants defining the expected useful life of these assets?

4. Has company ever changed its depreciation/ amortization method of these assets - what were key reasons and how the most appropriate depreciation/ amortization method was/ were selected?

5. Whether there are any possible problems and issues relating depreciation/ amortization of these assets the company may face in the nearest future?

The Author delivered questionnaire to all 28 Latvian companies listed in Baltic stock exchange. In order to reach the key goal of this article Author analysed answers received (totally from 26 companies). Based on results obtained Author developed recommendations what kind of aspects companies should consider analysing information about depreciation/ amortization of long-lived non-financial assets in financial statements and also issues ones should consider selecting the most appropriate amortization/ depreciation method of nonfinancial long-lived assets.

\section{RESULTS AND CONCLUSIONS OF THE RESEARCH PROCESS}

In this research nasdaqomxbaltic.com site was used to study financial statements per financial year 2014 of all 28 Latvian companies listed in the Baltics stock exchange. The Author investigated that researched companies represented totally 8 different industries: consumer goods $-32 \%$, production $-29 \%$, healthcare $-14 \%$; base materials $-11 \%$, telecommunication $-3 \%$, improvements, technology and finance $-3 \%$.

In most of cases long-lived non-financial assets constitute also considerable part of companies' total assets in its statements of financial position or balance sheets. In average this proportion in balance sheets of Latvian companies listed in Baltic stock exchange was 48\%. Nevertheless, in most of these companies this percentage was higher and even up to $97 \%$. 
THE IMPACT OF LONG-LIVED NON-FINANCIAL...

Table 2. Long-lived non-financial assets in balance sheet of Latvian listed companies in Baltic stock exchange

\begin{tabular}{|c|c|c|c|c|}
\hline & Company & $\begin{array}{l}\text { Value of BS, } \\
\text { FY } 2014 \text { (EUR) }\end{array}$ & $\begin{array}{c}\text { Non-financial } \\
\text { long-lived assets, FY } \\
2014 \text { (EUR) }\end{array}$ & $\begin{array}{c}\text { Proportion } \\
\text { of long-lived assets } \\
(\%)\end{array}$ \\
\hline 1 & AS Baltic Telekom & 2329019 & - & $0 \%$ \\
\hline 2 & AS Brīvais Vilnis & 8908364 & 4031823 & $45 \%$ \\
\hline 3 & $\begin{array}{l}\text { AS Daugavpils Lokomotīvju remonta } \\
\text { rūpnīca }\end{array}$ & 27287823 & 16046885 & $59 \%$ \\
\hline 4 & AS Ditton pievadkēēžu rūpnīca & 11280116 & 5818535 & $52 \%$ \\
\hline 5 & AS Grindeks & 160006467 & 78396714 & $49 \%$ \\
\hline 6 & AS Grobina & 18843583 & 15223427 & $81 \%$ \\
\hline 7 & AS Kurzemes Atslēga 1 & 1906371 & 702764 & $37 \%$ \\
\hline 8 & Kurzemes CMAS & 1669729 & 908057 & $54 \%$ \\
\hline 9 & AS Latvijas Balzāms & 123497624 & 53577753 & $43 \%$ \\
\hline 10 & AS Latvijas Gāze & 747970 & 563904 & $75 \%$ \\
\hline 11 & AS Latvijas Jūras medicīnas centrs & 7246744 & 5059945 & $70 \%$ \\
\hline 12 & AS Latvijas Kuǵniecība & 60957855 & 2310338 & $4 \%$ \\
\hline 13 & AS Latvijas tilti & 24964140 & 9113038 & $37 \%$ \\
\hline 14 & AS Olainfarm & 106723000 & 53522000 & $50 \%$ \\
\hline 15 & $\begin{array}{l}\text { AS Rīgas autoelektroaparātu } \\
\text { rūpnīca }\end{array}$ & 5726988 & 4000124 & $70 \%$ \\
\hline 16 & AS Rīgas elektromašīnbūves rūpnīca & 39197228 & 22471218 & $57 \%$ \\
\hline 17 & AS Rīgas farmaceitiskā rūpnīca & 2141327 & 566958 & $26 \%$ \\
\hline 18 & $\begin{array}{l}\text { AS Rīgas juvelierizstrādājumu } \\
\text { rūpnīca }\end{array}$ & 1566887 & 187914 & $12 \%$ \\
\hline 19 & AS Rīgas kuǵu būvētava & 46854780 & 30024202 & $64 \%$ \\
\hline 20 & AS SAF Tehnika & 12076449 & 728993 & $6 \%$ \\
\hline 21 & AS Saldus mežrūpniecība & 31840134 & 20080685 & $63 \%$ \\
\hline 22 & AS Siguldas CMAS & 1564523 & 389839 & $25 \%$ \\
\hline 23 & AS Talsu mežrūpniecība & 1021129 & 646457 & $63 \%$ \\
\hline 24 & AS Tosmares kuǵubūvētava & 10288965 & 6182931 & $60 \%$ \\
\hline 25 & AS Valmieras stikla šḳiedra & 122995264 & 77049989 & $63 \%$ \\
\hline 26 & AS VEF & 5817411 & 5627504 & $97 \%$ \\
\hline
\end{tabular}




\begin{tabular}{|c|c|c|c|c|}
\hline & Company & $\begin{array}{l}\text { Value of BS, } \\
\text { FY } 2014 \text { (EUR) }\end{array}$ & $\begin{array}{c}\text { Non-financial } \\
\text { long-lived assets, FY } \\
2014 \text { (EUR) }\end{array}$ & $\begin{array}{c}\text { Proportion } \\
\text { of long-lived assets } \\
\text { (\%) }\end{array}$ \\
\hline 27 & AS VEF Radiotehnika RRR & 8012134 & 7443213 & $93 \%$ \\
\hline 28 & AS Ventspils nafta & 315336468 & 52997 & $0 \%$ \\
\hline \multicolumn{4}{|r|}{ Average: } & $48 \%$ \\
\hline
\end{tabular}

S o u r c e : Nasdaq.com.

The analysis of IAS16 and IAS38 application was conducted using the example of Latvian companies listed in the Baltic stock exchange. The main sources of information used were the company financial statements for the financial year 2014 as well as additional information in the form of clarifications and analyzed data obtained from the questionnaire developed by the Author and filled by 26 out of 28 Latvian listed companies in Baltic stock exchange. The Author's conclusions and recommendations can be used not only to improve the long-lived asset management policy in the company system of corporate governance, but also may be useful for any company developing new or assessing existing process of measuring and valuing company's non-financial long-lived assets, as well as may be taken into consideration by shareholders (potential, actual) and financial analysts.

\section{ACCOUNTING PRACTICE RELATING DEPRECIATION/ AMORTIZATION OF LONG-LIVED NON-FINANCIAL ASSETS IN LATVIAN COMPANIES LISTED IN BALTIC STOCK EXCHANGE - RESULTS OF QUESTIONNAIRE}

The aim of RQ1 and RQ2 was to check whether Latvian companies listed in Baltic stock exchange present the information relating depreciation/ amortization of long-lived assets correctly and in accordance with definite accounting standards and regulations as well based on specific of company's business. Also, to identify, what kind of issues should company selecting the most appropriate amortization/ depreciation method of non-financial long-lived assets.

\section{Q1: What depreciation/ amortization methods are applied?}

Analysing results obtained the Author came to the following general conclusions on the information relating depreciation/ amortization methods selected are presented below: 
- Most of companies apply the straight-line method - $96 \%$, only $4 \%$ of companies apply diminishing balance method, and there are no any company applying units production method.

- In accordance with Latvian and international accounting standards there are three different depreciation/ amortization methods of long-lived non-financial assets. Choice of it is very important, because also the company's cost structure has strongly influenced by these fixed - depreciation/ amortization costs. Therefore, based on depreciation/ amortization method applied accounting result per particular period also can differ. In order to ensure positive results, the company has to earn relatively large amount of gross profit before it begins to earn a net profit. Therefore, it is crucial that this kind of assets in financial statements are treated and presented correctly, in accordance with definite accounting standards and regulations as well based on specific of company's business. It is even more important because of nowadays global economic situation when non-financial long-lived assets management plays significant role also in stakeholders' decision-making processes concerning investing, financing, controlling and other activities.

\section{Q2: What were key reasons to select these methods?}

Depreciation/ amortization expenses are non-cash expenses without direct impact on the company's cash balance, but with the indirect impact on the income tax calculated from the net income. Therefore, the choice of the most appropriate depreciation/ amortization method for each company is very important process. The research results showed that the most common reason selecting the most appropriate depreciation/ amortization method of long-lived non-financial assets is useful life of long-lived non-financial assets - 51\%. But such important reason as planned economic benefit from assets used has indicated only by $18 \%$ from all respondents. Also $18 \%$ was indicating as the key reason company's established practice over time, but 13\% - category and depreciation rates of fixed assets for tax purposes.

\section{Q3: What were key determinants defining the expected useful life of these assets?}

Based on practice in Latvian companies listed in Baltic stock exchange the key determinants defining are the ones described in the table below. 
Table 3. Key determinants defining the expected useful life of assets

\begin{tabular}{|l|c|c|}
\hline \multicolumn{1}{|c|}{ Criterion } & Tangible assets (\%) & Intangible assets (\%) \\
\hline \hline Planned Economic benefits of the asset to be used & $0 \%$ & $52 \%$ \\
\hline Technological properties of asset & $34 \%$ & \\
\hline Physical deterioration & $32 \%$ & $21 \%$ \\
\hline Conditions of purchase contract & $0 \%$ & \\
\hline Obsolescence & $17 \%$ & $14 \%$ \\
\hline Situation in the market & $0 \%$ & \\
\hline Technological progress & $13 \%$ & $14 \%$ \\
\hline Other* & $4 \%$ & \\
\hline \hline
\end{tabular}

S o u r c e : The Author's own study.

The general conclusions on the information relating key determinants defining the expected useful life of long-lived non-financial assets are different for tangible assets - e.g. technological properties of these asset, physical deterioration, obsolesce, etc. and intangible ones - e.g. planned economic benefits of asset, conditions of purchase contract and even situation in the market.

\section{Q4: Has company ever changed its depreciation/ amortization method of these assets? \\ What were key reasons and how the most appropriate depreciation/ amortization method was/ were selected?}

Only $21 \%$ of all companies answered that it has changed depreciation/ amortization method, but $79 \%$ of respondents answered with no. Reasons to change the method for tangible assets were decision of company's management, chief executive officer, accountant and change of chief accountant, economic considerations, and useful life of the asset, before was applied geometric method. But reasons for intangible assets, if the company has - useful life of the asset and planned active usage period of the asset.

Q5: Whether there are any possible problems and issues relating depreciation/ amortization of these assets the company may face in the nearest future?

Replies received were the following - there are no any issues, do not planned to have this type of issues in the future, consider all costs developing intangible 
assets, and intangible assets are insignificant proportion of total assets, therefore, do not consider this issue. The research results presented above show that most of companies do not predict any possible problems or issues relating depreciation/ amortization of long-lived non-financial assets. Based on this result the Author can conclude that rules and regulations are clear, correct and support companies in their process of efficient long-lived assets management process.

\section{ConCLUSIONS}

The results of the research conducted by the Author of this article show that in most of cases long-lived non-financial assets constitute also considerable part of companies' total assets in its statements of the company's financial position or balance sheet. Therefore, the choice of depreciation/ amortization method of long-lived non-financial assets significantly influences result in company's financial statements per particular period.

There are no one and the most suitable depreciation/ amortization method for long-lived non-financial assets for all companies. The most suitable depreciation/ amortization method for one company could be not such a method for other company. It is very crucial that these assets owned by company are not only treated and presented correctly, in accordance with definite accounting legislation, but also are in line with company's business specifics. Since $96 \%$ of all Latvian listed companies apply straight-line method to depreciate/ amortize its long-lived non-financial assets the Author can conclude that there is an issue - not always the best and the most appropriate depreciation/ amortization method has been selected. Also, this has been confirmed because the selection criteria of the depreciation/ amortization method as most common reason was useful life of the asset - 51\%. Such important reason as planned economic benefit from assets used was indicated only by $18 \%$ from all respondents. Almost $80 \%$ of all respondents never have changed its depreciation/ amortization method. These results approved the Author's conclusion that companies should regularly consider appropriateness of the particular depreciation/ amortization method of long-lived non-financial assets especially in nowadays global economic situation.

The results of this research show that before company's management selects the most appropriate depreciation/ amortization method for company's long-lived non-financial assets it is necessary to take into account various cri- 
teria - industry company operates in, type and useful life of long-lived non-financial assets, economic situation of the company, situation/ legislation, etc. in the country the company operates in, global economic situation, company's investment strategies and possibilities, asset's depreciable/ amortizable amount. The theoretical research indicates there is no such a method that could be the best one and applied in all companies. However company's management and shareholders or even financial analysts should regularly evaluate the potential risk of obsolescence of long-lived non-financial assets belonging to the particular company. This information will help to identify situations when company's management tries to manipulate with the net income per particular period by increasing/ decreasing depreciation/ amortization expenses. This could be done in various ways - changing depreciation method, increasing/ decreasing period of an asset's useful life, deciding to capitalize or not the elements of the acquisition cost. Also, it could be the situation, that the management identify situation, when depreciation/ amortization method should be changed.

\section{REFERENCES}

Accountancy (1980). Lonrho changes its accounting policy on excel depreciation. Accountancy, 91(1040), 19.

Annual Accounts Law (1992 the amendments), 14 October 1992, http://www.fm.gov.lv/ files/files/Annual_Accounts_Law.pdf (accessed: 13. 04. 2012).

Aparicio J., \& Sánchez-Soriano, J. (2008). Depreciation games. Annals of Operations Research, 158 (1), 205-218. http://dx.doi.org/10.1007/s10479-007-0238-5.

Archibald T. R. (1967). The Return To Straight-Line Depreciation: An Analysis of A Change In Accounting Method. Journal of Accounting Research, 5(3), 164-180. http://dx.doi.org/10.2307/2489918.

Bain, J. S. (1937). Depreciation Pricing And The Depreciation Function 1. The Relation of Depreciation Policy To Short-Run Output. Quaterly Journal of Economics, 51(4), 705-711.

Barnea, A. (1972). A Note On The Cash-Flow Approach To Valuation And Depreciation Of Productive Assets. Journal of Financial \& Quantitative Analysis, 7(3), 1841-1846. http://dx.doi.org/10.2307/2329807.

Barth, M. E., Cram, D. P., \& Nelson, K. K. (2001). Accruals and the prediction of future cash flows. The Accounting Review, 76 (1), 27-58. http://dx.doi.org/10.2308/ accr.2001.76.1.27.

Beaver, W. H., \& Dukes, R. E. (1974). $\delta$-Depreciation Methods: Some Analytical Results. Journal of Accounting Research, 74 (12), 205-215. http://dx.doi. org/10.2307/2490372.

Baxter, W. T. (1970). Depreciating Assets: The Forward-looking Approach To Value. Abacus, 6 (2), 120-131. http://dx.doi.org/10.1111/j.1467-6281.1970.tb00442.x. 
Ben-Shahar, D., \& Sulganik., E. (2009). Fair Depreciation: A Shapley Value Approach. B.E. Journal of Theoretical Economics: Topics in Theoretical Economics, 9 (1), 1-16. http://dx.doi.org/10.2202/1935-1704.1531.

Breuer, A., Frumuşanu, M. L., Pereș, C. E., \& Breuer, B. G. (2011). Depreciation of Fixed Assets in the Construction Field. Annals of Eftimie Murgu University Resita, Fascicle II, Economic Studies, 24-29.

Birky, K., \& Grimstad, E. (2013). Decoding depreciation. Water Environment \& Technology, 25(2), 62-63.

Boudreaux, D. O., Rao, S., Underwood, J., \& Rumore, N. (2011). Measuring Lossed For Small Business Interruption Claims: Depreciation Expenses. Journal of Applied Business Research, 27 (2), 105-114.

Brannon, G.M. (1972). Tax Policy and Depreciation: The Case for ADR. Journal of Finance, 27 (2), 525-533. http://dx.doi.org/10.1111/j.1540-6261.1972.tb00980.x.

Brief, R.P. (1967).A Late Nineteenth Century Contribution To The Theory Of Depreciation. Journal of Accounting Research, 5(1), 27-38. http://dx.doi.org/10.2307/2489984.

Brief, R. P. (1968). Depreciation Theory and Capital Gain. Journal of Accounting Research, 6 (1), 149-152. http://dx.doi.org/10.2307/2490133.

Brigham, E. F. (1966). Depreciation and Reported Profits. Journal of Finance\& Quantitative Analysis, 1 (4), 112-114.

Brigham, E.F. (1968). The Effects of Alternative Depreciation Policies on Reporting Profits. Accounting Review, 43 (1), 4-46.

Brundage, P.F. (1935). Depreciation - An Old Subject with A New Importance. Harvard Business Review, 13 (3), 334-344.

Budeanu, M. (2012). Research and development as fertile ground for creative accounting. Metalurgia International, 17 (2), 146-148.

Butler, G., \& Crawford, L. (2001). The impact of price controls on accounting policy choise: an international study of depreciation methods in the electricity industry. Contemporary Issues in Accounting Regulations, 187-198. http://dx.doi. org/10.1007/978-1-4615-4589-7_11.

Cameron-Smith, I., \& Mattiiussi, F. (1989). Intangible valuation - the expert view. Accountancy, 25-26.

Cernuşca, L. (2009). Methods, Techniques and Practive Of Creative Accounting For Depreciation. Agricultural Management/ Lucrari Stiintifice Seria I, Management Agricol, 11 (3), 1-8.

Chou, Y., Yang, C., \& Pao, C. (2012). Strategic group analysis of the flexible display industry using patent value depreciation model. International Journal of Technology Transfer \&Commercialization, 11 (3/4), 247-370. http://dx.doi.org/10.1504/ ijttc.2012.052419.

Coggins, M. (1995). Accounting for tangible fixed assets. Accountancy, 86-88.

Davidson, S. (1950). Depreciation and Profit Determination. Accounting Review, 25 (1), $45-45$.

Dilley, S. C., \& Young, J. C. (1994). A pragmatic approach to amortizartion of intangibles. CPA Journal, 64 (12), 46-51. 
Dyckman, T. R., Nelson, M., Dukes, R. E., Zin, M., Davis, C. J., \& Conrod, J. E. D. (1992). International Accounting, $6^{\text {th }}$ Canadian Edition, Richard D.Irwin Inc. chapter 12 , Capital Assets: Depreciation and Impairment, 538.

Eisner, R. (1955). Accelerated Depreciation: Some Further Thoughts. Quaterly Journal of Economics, 69 (2), 285-296.

Feinschreiber, R. (1969). Accelerated Depreciation: A Proposed New Method. Journal of Accounting Research, 69 (7), 17-21.

Girish, K. (2010). Depreciation and Reserves, [in:] Corporate Accounting, Global Media, 169.

Girish, K. (2010). Fixed Assets Accounting, [in:] Corporate Accounting, Global Media, 171-190.

Hellmuth, J. R., \& William, F. (1955). Depreciation and the 1954 Internal Revenue Code. Journal of Finance, 10 (3), 326-349. http://dx.doi.org/10.2307/2976882.

Huagan, N., \& Diewert, E. (2011). Estimation of R\&D depreciation rates: a suggested methodology and preliminary application. Canadian Journal of Economics, 44 (2), 387-412. http://dx.doi.org/10.1111/j.1540-5982.2011.01638.x.

Hwang, J. C. (1997). The Form And Rate Of Physical Depreciation In Canadian Industries. Journal of Economic \& Social Measurement, 23(2), 87-133.

Hwang, J. C. (2002/2003). Forms and rates of Economic and physical depreciation by type of assets in Canadian industries. Journal of Economic \& Social Measurement, 28 (3), 89-108.

International Accounting Standard 16, http://www.ifrs.org/Documents/IAS16.pdf (accessed: 01.04.2015).

International Accounting Standard 38, http://www.iasplus.com/en/standards/ias38 (accessed: 01.04.2015).

Ijiri, Y., \& Kaplan, R.S. (1970). Sequential Models in Probabilistic Depreciation. Journal of Accounting Research, 8 (1), 34-46.

Ilincuta, L. (2013). Resumptions and developments regarding the management of the depreciation methods. Metalurgia International, 18 (3), 202-213.

Jackson, S. B., Rodgers, T. C., \& Tuttle, B. (2010). The effect to firm's depreciation method choise on assets selling price. Accounting. Organizations \& Society, 757-774. http:// dx.doi.org/10.1016/j.aos.2010.09.004.

Jermakowicz, E. K., \& Epstein, B. J. (2011). Accounting Policy Options in IFRS. CPA Journal, 81(8), 44-49.

Jones, J. R. (1980). Assets Depreciation. Harvard Business Review, 58(6), 78-86.

Koowattanatianchai, N., Wang, J., \& Charles, M.B. (2012). The merits of accelerated depreciation for promoting investment in clean transport technologies: A simulation study in the Australian rail freight industry. Transportation Research: Part D, 17 (8), 578-584. http://dx.doi.org/10.1016/j.trd.2012.06.007.

Kim, I., \& Seo, H .L. (2009). Depreciation and transfer of knowledge: an empirical exploration of a shipbuilding process. International Journal of Production Research, 47 (7), 1857-1876. http://dx.doi.org/10.1080/00207540701499481. 
Lepãdatu, G. (2009). Property, plant and equipment in the metallurgical field. Metalurgia International, 53-55.

Lev, B., \& Theil, H. (1978). A Maximum Entropy Approach to the Choice of Asset Depreciation. Journal of Accounting Research, 16 (2), 286-293.

Levy, H., \& Arditti, F.D. (1973). Valuation Leverage, And The Cost Of Capital In The Case of Depreciable Assets. Journal of Finance, 28 (3), 687-693.

Latvian Accounting Standard nb.7, Long-lived Non-financial Assets. http://likumi.lv/ doc.php?id=124600 (accessed: 1.04 .2015 ).

Livingstone, J. L. (1969). Accelerated Depreciation, Tax Allocation, And Cyclical Asset Expenditures of Large Manufacturing Companies. Journal of Accounting Research, 7 (2), 245-256.

Luger, M. I. (1986). Depreciation Profiles And Depreciation Policy In A Spatial Context. Journal of Regional Science, 26 (1), 141-159.

Mohman, M. B. (2009). Depreciation of Airplanes and Garbage Trucks: Information Value and Fraud Prevention in Financial Reporting. Issues in Accounting Education, 24 (1), 105-107. http://dx.doi.org/10.2308/iace.2009.24.1.105.

Mykolaitiene, V., Vecerskiene, G., Jankauskiene, K., \& Valanciene, L. (2010). Pecularities of Tangible Fixed Assets Accounting. Engineering Economics, 21 (2), 142-150.

Nasdaq Baltic Equity List. http://www.nasdaqomxbaltic.com/market/?pg=mainlist \&lang=en (accessed: 22.03.2015).

Noland, T. R. (2010). The Sum-Of-Years' Digits Depreciation Method: Used by SEC Filers. Journal of Finance \& Accounting, 5, 1-12.

Most, K. (1984). Depreciation Expense and the Effect of Inflation. Journal of Accounting Research, 22 (2), 782-788.

O’Bannon, I.M. (2011). Effective Asset Management Is More Than Depreciation. CPA Practice Advisor, 21 (8), 31-31.

Rajan, M., \& Reichelstein, S. (2009). Depreciation Rules and the Relation between Marginal and Historical Cost. Journal of Accounting Research, 47 (3), 823-865.

Radu, D., \& Marius, D. (2011). Issues Related to the Accounting Treatment of the Tangible and Intangible Assets Depreciation. Annals of the University of Oradea, Economic Science Series20(2), 498-502.

Stadig, M. (2011). Estimating Depreciation for Property Assessment Purposes. Journal of Property Assessment \& Administration, 8 (4), 5-13.

Sok-yon, K., \& Yuping, Z. (2010). Information Content and Value Relevance of Depreciation: A Cross-Industry Analysis. Accounting Review, 85 (1), 227-260. http://dx.doi. org/10.2139/ssrn.1394765.

Storchmann, K. (2004). On the Depreciation of Automobiles: An International Comparison. Automobiles - Transportation, 31 (4), 371-408. http://dx.doi.org/10.1023/ b:port.0000037087.10954.72.

Trifan, A., \& Anton, C.E. (2010). Tax Depreciation Versus Accounting Depreciation in Romania After Joining The European Union. Bulletin of the Transilvania University of Brasov. Series V: Economic Sciences, 3, 335-340. 
Valipour, H., Moradi, J., \& Farzanfar, F. (2013). The Relationship Between Information Content of Depreciation and Abnormal Return, Stock Price and Future Benefits in Manufacturing Companies in Tehran Stock Exchange (TSE). International Journal of Contemporary Research in Business, 4 (9), 522-537.

Voss, W. M. (1968). Accelerated Depreciation And Deferred Tax Allocation, Journal of Accounting Research, 6 (2), 262-269. http://dx.doi.org/10.2307/2490240.

Watts, M. M. (2011). Measuring the Value of 100\% First-Year Depreciation. CPA Journal, 81 (11), 52-57.

Wolk, H. I. (1970). Current Value Depreciation: A Concept Clarification. Accounting Review, 45(3), 544-552.

Wong, A., \& Pitt, A.J. (2012). Depreciation and Changes in Use of Real Property. Tax Adviser, 43 (10), 648-650.

Wright, F.K. (1964). Towards a General Theory of Depreciation. Journal of Accounting Research, 2 (1), 80-90. 